\title{
The subdivision and zonation of interglacial periods
}

\author{
by C. Turner and R. G. West \\ Subdepartment of Quaternary Research, Cambridge
}

With 3 figures and 2 tables

$\mathrm{Su} \mathrm{m} \mathrm{mary}$. It is becoming ever more difficult to study and compare the increasing number of pollen diagrams from sites in different parts of North-West Europe or from different interglacial periods, because of the diversity of zonation schemes used by different authors. IVERSEN (1958) and ANDERSEN (1966) have nevertheless shown similar cycles of vegetational and edaphic changes have taken place during each of the major interglacial periods.

The authors here suggest that during each interglacial a series of four distinct sub-periods of vegetational development can be recognised, and that these can be regarded as natural biostratigraphic zones based on the pollen assemblage characters. These are: Zone I the Pre-temperate zone dominated by Betula and Pinus, Zone II the Early-temperate zone showing the dominance of mixed oak forest trees, Zone III the Late-temperate zone increasingly dominated by late-immigrating temperate trees such as Carpinus and Abies and Zone IV the Post-temperate zone again characterised by boreal trees, Pinus and Betula. This zonation scheme can be applied to almost all interglacial pollen diagrams from North-West Europe. Minor vegetational changes, whether regional, local or seral, can be described as subzones, without prejudicing the major descriptive and correlative functions of the zonation scheme.

$\mathrm{Z}$ us a mmenf a s ung: Es wird immer schwieriger, vergleichende Studien über die zahlreichen Pollendiagramme eines Interglazials innerhalb Nordwesteuropas oder aber verschiedener Interglaziale dieses Raumes zu machen, und zwar wegen der Mannigfaltigkeit der Zonierungssysteme, die die einzelnen Autoren anwenden. Dennoch haben aber IvErSEN (1958) und ANDERSEN (1966) gezeigt, daß in jedem der bisher untersuchten Interglaziale ähnliche Zyklen der Vegetationsentwicklung und der Bodenbildung abgelaufen sind.

Die Verfasser legen dar, daß in jeder Interglazialzeit 4 Perioden der Vegetationsentwicklung festgestellt werden können und daß diese als natürliche biostratigraphische Zonen angesehen werden können, basierend auf dem Charakter der Pollengemeinschaften. Diese Perioden sind: Zone I, die Pre-temperate Zone, Betula und Pinus dominieren; Zone II, die Early-temperate Zone, Vorherrschaft der Bäume des Eichenmischwaldes; Zone III, die Late-temperate Zone, in zunehmendem Maße beherrscht durch spät einwandernde wärmeliebende Bäume, wie Carpinus und Abies; Zone IV, die Post-temperate Zone, wiederum beherrscht durch boreale Bäume, wie Pinus und Betula. Diese Zonierung kann für fast alle interglazialen Pollendiagramme Nordwesteuropas verwandt werden. Geringe Veränderungen der Vegetation, und zwar regional, lokal oder seral, können als Unterzonen beschrieben werden, ohne die Hauptzüge und den Zweck dieses Zonierungssystems zu stören.

Every year sees the publication of more papers on climatic and vegetational changes during the Pleistocene, and our knowledge of these features is constantly expanding. In particular, the study of interglacial deposits has emphasised the strong parallelism of vegetational, climatic and edaphic development during each of the three most recent interglacial periods, the Cromerian, the Holsteinian and the Eemian, and likewise the Flandrian postglacial period.

This parallelism has been considered by IVERSEN (1958) and by ANDERSEN (1966), but the descriptive terms which they propose for the interglacial cycle have not yet been generally adopted by other workers to bring separate interglacial studies into a general perspective. These terms are not free from ambiguity for historical reasons, as is discussed below, but the need for an accepted framework of this kind is becoming increasingly urgent as the sheer bulk of published data increases.

A number of terms have been used to characterise groups of floristic elements according to their periods of expansion during post-glacial and interglacial time, or alternatively to define different periods of vegetational and climatic development during interglacial and glacial stages. 
The originator of such concepts was von Post (1946) who coined the term 'medioratic' for vegetational elements which expanded towards the hypsithermal maximum of the Post-glacial period. He contrasted these with 'terminocratic' vegetation elements, species which have expanded or re-expanded at the expense of mediocratic elements since the hypsithermal maximum or were prominent during the opening phases of the Postglacial. This classification, which was also applied to interglacial pollen diagrams, is strongly influenced by the concept of vegetational revertence, also pioneered by voN Post. Although von Post's listing of individual elements is unsatisfactory on ecological grounds (ANDERSEN, 1966), his basic concepts are still significant.

FIRBAS (1949) developed a very similar scheme but pointed out that, at least in Germany, the floristic elements of the latest period of the Postglacial are not in fact identical with those of the Boreal period, and that a threefold division of vegetation elements would be more accurate. He proposed the terms archaeocratic, mesocratic and telocratic to describe these. For interglacial periods he suggested a further term, teleutocratic, to cover the vegetation of the final stages, which have as yet no parallel in Postglacial vegetational history.

Iversen (1958) used Firbas' terminology in part, and extended it to describe not merely the vegetation elements but the actual stages of an interglacial/glacial cycle. His concepts are best illustrated by his own diagrammatic summary (Fig. 1). It is evident that his use of the term telocratic carries with it quite different and much severer climatic implications than those associated with FIRBAs' telocratic vegetation elements, as originally defined.
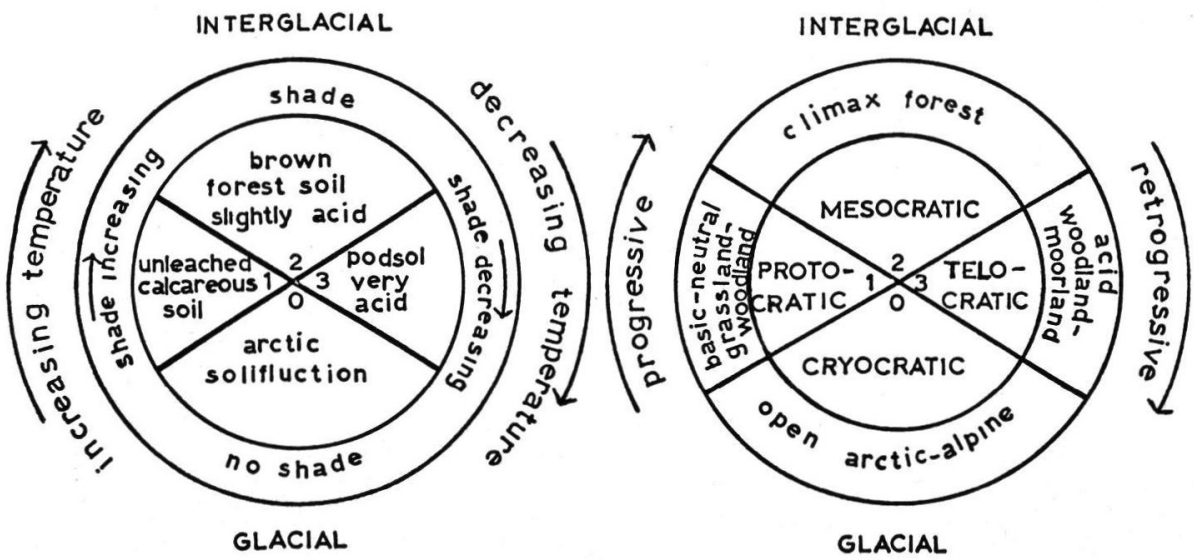

Fig. 1. Summary of the glacial/interglacial cycle (after IvERSEN 1958).

ANDERSEN (1966), having made very thorough studies both on the vegetational succession and on the lake development of various interglacial deposits in Denmark, interpolates a further oligocratic stage between IVERSEN's mesocratic and telocratic. This oligocratic stage is characterised by distinct soil degeneration and consequent vegetational changes that set in during the temperate phases of the interglacial, quite independently of climatic or at least thermal change. By contrast the telocratic stage shows a real climatic decline with lowering of temperature and the eventual disruption of the forest vegetation. In outline this classification seems very satisfactory, though it is perhaps a pity that the term telocratic is used since it has other connotations.

The zonation of interglacial periods is likewise a very confused matter. Interglacial zones are essentially assemblage zones, and, as biostratigraphic units, should be based on 
the assemblage characters of the fauna and flora. In practice the zones of interglacial periods are defined almost exclusively on vegetational characteristics, because pollen analysis is the dominant technique of investigation.

The earliest detailed vegetational zoning system for an interglacial was that put forward by JESSEN and Milthers (1928) and is still in current use for describing most Eemian and occasionally Holsteinian pollen diagrams. This system divides an interglacial, together with its adjacent late and early glacial periods, into a series of vegetational zones $(\mathrm{a}-\mathrm{k})$ based on distinct changes in the character and species dominance of the forest or open vegetation communities. Originally the number of zones and the dominant species, usually trees, used to define them depended entirely on the vegetational succession of the Eemian interglacial at particular sites in Denmark and North Germany. It has, however, proved possible and very useful to apply this scheme to Eemian interglacial sites across North-west Europe, although it has sometimes been necessary to modify and adapt the specific characteristics of particular zones, for example, in areas where Abies occurred during the latter part of the interglacial. It could be commented that the widespread application of this zonation system to Eemian deposits does reflect the uniformity of the vegetational development across North-West Europe during that interglacial. Nevertheless Polish workers have tended to use a different scheme (SZAFER, 1953) to describe their Masovian II (Eemian) deposits.

The success of the JeSSEN and MiLThers zonation scheme is based on two factors. Firstly its zones are based on fairly clear-cut changes in the vegetational pattern, secondly it has been a valuable tool in the general correlation of vegetational change from a large number of Eemian sites across Europe.

It is well known that the biostratigraphic zonation of Flandrian (Postglacial) deposits has become excessively complicated. This is due, in part, to the much larger number of studies that have been carried out, in contrast to those on interglacial deposits, but also to the more extensive latitudinal area over which it has been possible to make such studies (e. g. Scandinavia) and to complications associated with anthropogenic disturbance of the vegetation. The result, at any rate, is that individual workers have set up a large variety of differently numbered zonation schemes based on successions of locally or regionally important and distinctive vegetational changes, but which can only be correlated with one another after painstaking comparison of pollen diagrams, or more usually by the saving grace of radiocarbon dating. It seems evident that absolute time zones, based on radiocarbon dates, will eventually replace biostratigraphic assemblage zones as the basic units for describing the Flandrian period.

The Holsteinian interglacial is less well studied and understood than the Eemian, except in the British Isles and Poland. Until recently most Holsteinian pollen diagrams from Germany and Holland were either fragmentary or stratigraphically ill-defined. In consequence no complete or accepted zonation system has been evolved for this interglacial as it has for the Eemian. In addition it has become increasingly clear that the vegetational development of the Holsteinian interglacial was far less uniform across Northern Europe than was that of the Eemian.

As a result of these factors, many workers have applied their own schemes of zonation to Holsteinian deposits on which they are working. In England the accepted zonation scheme has been that of WeST (1956). For Ireland, Jessen, ANDERSEN and FARrington (1959) have produced a similar but rather more complicated scheme. ZAGWIJN has presented a fragmentary zonation for Dutch diagrams (DE RIDDER \& $Z_{A G W I J N}$, 1962). German Holsteinian diagrams tend to be either unzoned or follow the zonation of SELLE (1955) or else the Eemian type zonation of Jessen and Milthers. In Denmark ANDERSEN (1963) proposed a series of five zones to describe his pollen diagram from Tornskov, but in a later publication (ANDERSEN, 1965) he supercedes this with an expanded scheme of 
nine pollen zones following his investigations at Vejlby. For many years the standard scheme of zonation in Poland has been that of Szafer (e.g. as in Szafer, 1953), a relatively simple one consisting of four pollen zones, but in 1957 ŚRODOŃ described the Masovian I (Holsteinian) deposits at Gościęcin using a more complicated zonation scheme covering the previous glaciation and an interstadial period as well as the interglacial vegetational succession. An attempt is made to compare these various zonation schemes in Table 1.

Table 1

Comparison of different Holsteinianzonation schemes

Proposed general zonation (TURNer \& West)

Eng 1 a n d

WeST (1956)

I re la nd

Jessen, Andersen \&

FARRINGTON (1959)

WATTS (1967)

$\mathrm{Netherlands}$

DE RIDDER \&

ZAGWIJN (1962)

Denmark \& Germany Jessen \& Milthers (1928)

SElle (1955)

ANDERSEN (1963)

ANDERSEN (1965)

Pol and

SZAFER (1953)

ŚRODOŃ (1957)

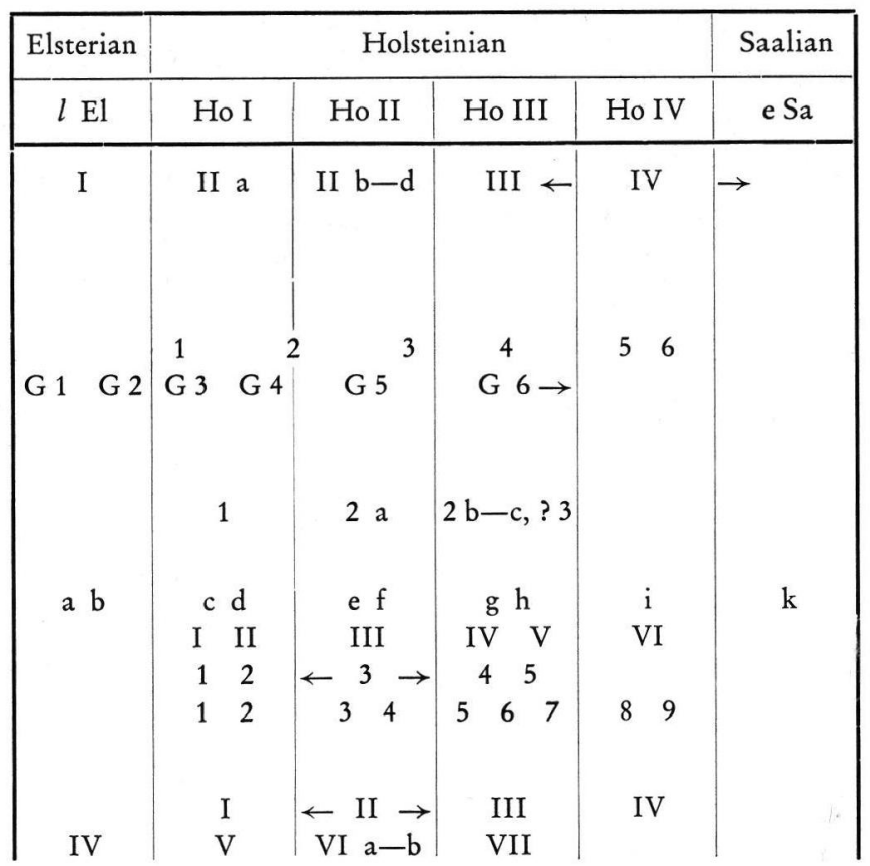

Generally these Holsteinian zones are based on definite vegetational changes, tho igh sometimes, perhaps, of only local significance. No good comparative standard has 1 -en available, because of the paucity of Holsteinian pollen diagrams. Amidst the confusion caused by these diverse attempts at zonation, it has become increasingly difficult to either correlate or even compare the vegetational succession of this interglacial in different areas. Furthermore no absolute dating methods are at present available to provide an alternative yardstick for describing interglacial time.

At present much better and more complete interglacial pollen diagrams are brcoming available for the Eemian and Holsteinian periods and also for the Cromerian (R. ( $)$. WEST unpublished material). These give a much fuller picture of the fundamental pattarns of vegetational change, which has resulted in the classification of interglacial cycles theady discussed. Further, it is now much easier to understand and compare the local and regional variations of vegetational development from different areas within the framework of this classification.

It has been shown that most of the zonation schemes proposed for the Holsteinian interglacial, though they succeed in describing the assemblage characters of the vagetation, are both inadequate and disadvantageous for the subsidiary but important purpose of 
correlation. It is suggested that a standard zonation framework for at least the three latest interglacial periods in North-West Europe is both possible and necessary. The zones must be based broadly enough to serve the purpose of correlating the vegetational development over an area which is latitudinally and biogeographically fairly uniform. The zones must be simple, clearly defined and significant enough to obtain widespread recognition and acceptance. Zones have diminished significance if they are used merely as instruments to describe in detail regional fluctuations of vegetation, but it is essential to have a subsidiary framework to record such regional phenomena. Despite its utility for Eemian diagrams the JESSEN and MILTHERS zonation scheme is not adequate for a consistent application to interglacial pollen diagrams, and certainly not for an interglacial period as complex vegetationally as the Holsteinian.

When an interglacial period is considered as a whole, it seems possible to recognise four main sub-periods of vegetational development, which may be regarded as natural biostratigraphic zones and which can be distinguished quite easily in pollen diagrams from the Cromerian, Holsteinian and Eemian interglacials and also in part from the Flandrian Post-glacial. At the same time these are true assemblage zones in the sense that in each interglacial each zone can be characterised by a particular forest assemblage. These zones have close affinities to the interglacial stages recognised by ANDERSEN (1966) and may be defined as follows: -

Zone I The Pre-temperate zone.

This zone is characterised by the development and closing-in of forest vegetation after a late-glacial period. The forest dominants are generally boreal trees, particularly Betula and also Pinus, but light-demanding herbs and shrubs are also significant elements of the vegetation.

Zone II The Early-temperate or mesocratic zone.

This shows the establishment and expansion of mixed oak forest vegetation, typically with Quercus, Ulmus, Fraxinus and Corylus. During this zone the forest is thriving on rich soil conditions and achieves its maximum denseness and luxuriance.

Zone III The Late-temperate or oligocratic zone.

The onset of this zone is marked by the expansion of late-immigrating temperate trees, Carpinus and Abies, sometimes of Picea, and perhaps in terms of Flandrian vegetational history of Fagus. This expansion is generally accompanied by a progressive decline of the mixed oak forest dominants. This change in composition of the temperate forest appears to be a response to degenerating soil conditions rather than to specific climatic changes. ANDERSEN (1966) has demonstrated how this transition is also reflected by changes in contemporary lake sedimentation.

\section{Zone IV The Post-temperate zone.}

This shows a return to dominance of boreal trees, in particular of Pinus, Betula and Picea, together with a thinning of the forest and the gradual development of open communities, particularly damp heathland. Temperate forest trees become virtually extinct. Ericaceous heaths may be particularly characteristic of this zone, but they often persist into the succeeding early-glacial period.

The terms protocratic and telocratic have been avoided as synonyms for the Pre- and Post-temperate zones since, sensu IVERSEN, they also cover the adjacent late- and earlyglacial periods. In North-Western Europe the glacial-interglacial boundaries are traditionally defined in pollen diagrams as the point where tree pollen totals first consistenly exceed those for non-tree pollen, though variation due to local vegetational influences has to be taken into account. A similar definition is used for the interglacial-glacial boundary at the end of the Post-temperate zone, though this can be more difficult to 


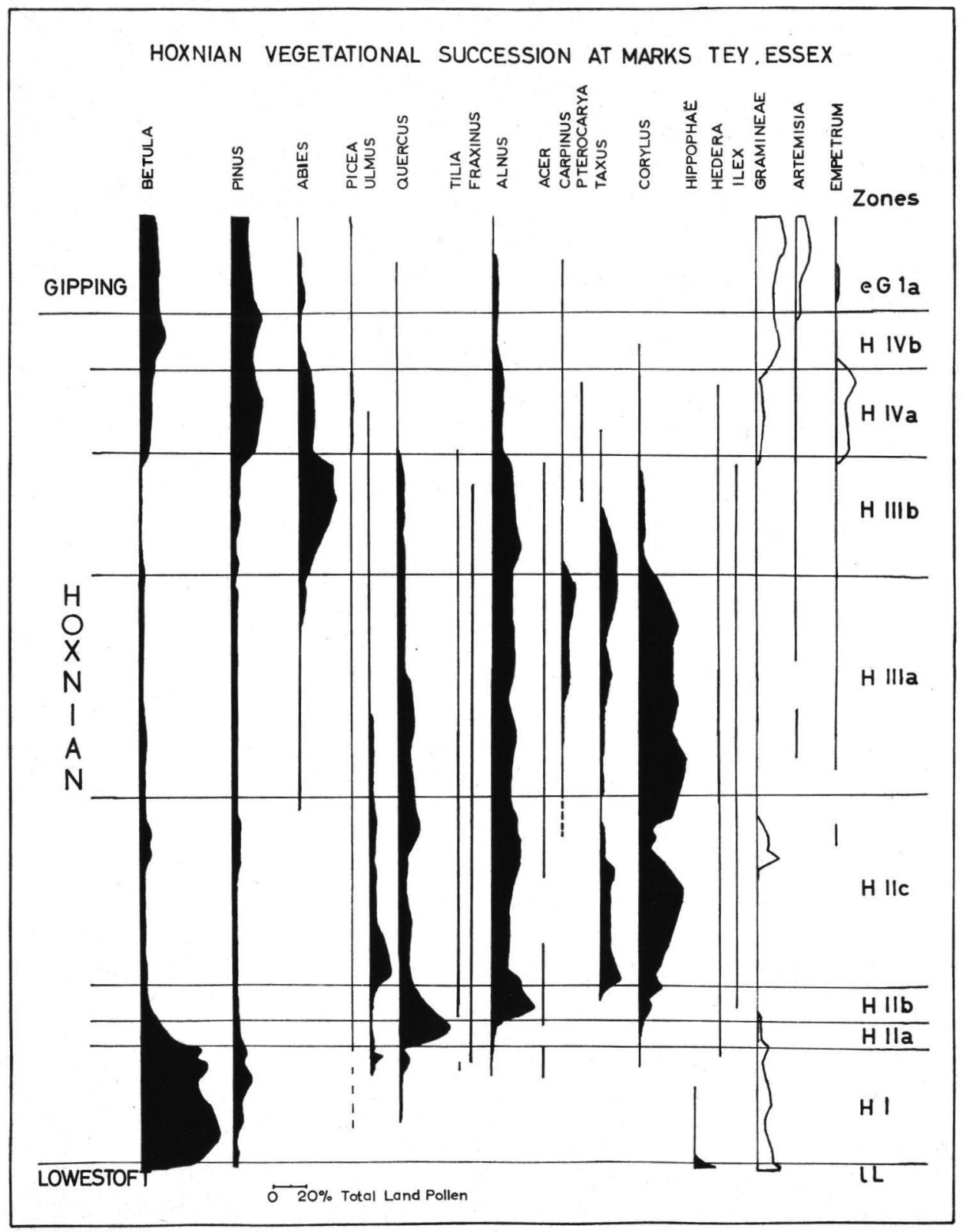

Fig. 2. Pollen diagram from the Holsteinian (Hoxnian) deposits at Marks Tey, England (TURNER 1968).

apply satisfactorily and consistently in practice. Nevertheless boundaries of this kind are taken as the lower and upper limits of the Pre- and Post-temperate zones respectively.

The breadth of these pollen zones means that in any extensive pollen diagram a single zone is likely to cover a number of distinct vegetational changes, whether of a regional, local or purely seral nature. It is suggested that these can best be described as numbered 
subzones (e.g. II a, b, c etc.) which may or may not be correlative over wider areas or with the subzones defined by other workers in other diagrams, but whose definition will not prejudice the general system of zonation.

As an example of this method of zonation Fig. 2 shows a composite pollen diagram from the Hoxnian (Holsteinian) interglacial deposits at Marks Tey, Essex, England (TuRNER, 1968) which covers the entire timespan of that interglacial. The four major biostratigraphic zones are clearly defined. The Early-temperate zone II has been subzoned according to the different phases of expansion of the mixed oak forest trees. Thus subzone II a is characterised by the dominance of Quercus pollen, II b by the expansion of Alnus and II c by increases in Ulmus and Taxus pollen. Likewise the subzones of the Late-temperate zone are based largely on the behaviour of the Carpinus and Abies pollen curves. In contrast, no attempt has been made to subdivide the Pre-temperate zone I in this diagram. Similarly in Fig. 3 a pollen diagram from Masovian II (Eemian) deposits in Poland is presented and zoned according to the same system (after SzAfER 1953, ŚRodoń \& Golabowa 1956).

Diagrams specially prepared by ANDERSEn (1966) for the Eemian deposits at Hollerup and the possibly Cromerian ones at Harreskov in order to demonstrate his subdivision of

\section{BEDLNO (Poland)}

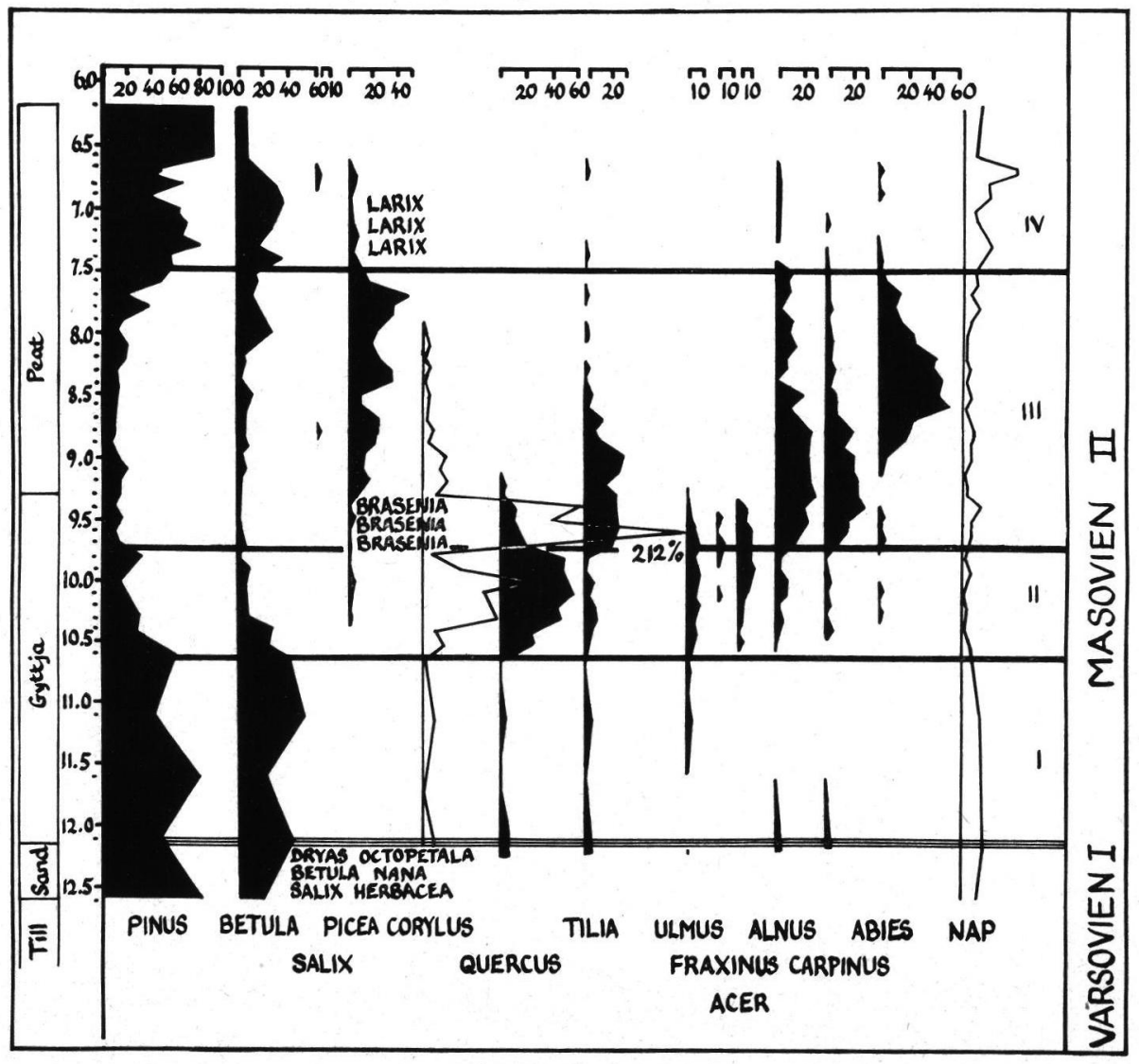

Fig. 3. Pollen diagram from the Eemian (Masovian II) deposits at Bedlno, Poland (after Szafer 1953, Środoń \& Golabowa 1956). 
the interglacial succession into stages, as already discussed (i. e. the zones here proposed) provide further examples of the application of this zonation scheme to other interglacial deposits in different parts of Europe. In these instances it is relatively simple to reinterpret ANDERSEN's own zonation of these diagrams as a series of subzones within the dominant four zone scheme. It is then much easier to discuss and compare vegetation patterns from different sites or even from different interglacial periods under these broad but uniform zonal headings.

A general nomenclatural scheme for the last three interglacial periods is summarised in Table 2. The zone numbers are prefixed with the initial letters of the interglacial concerned. The subdivision of glacial periods is much more complex and still very imperfectly understood, but it does seem desirable to use a similar system of nomenclature for the late- and early-glacial periods which are frequently represented in pollen diagrams. Consequently general zones such as $l$ We, the Late Weichselian and e Sa, the Early Saalian, which could be subzoned if desired, are included in this table, altough they may not be strictly the equivalent of the interglacial zones proposed.

Table 2

A zonal nomenclaturesystem fortheinterglacial periods of the Late and Middle Pleistocene

\begin{tabular}{|c|c|c|c|c|c|}
\hline Zone names and numbers & \multicolumn{4}{|c|}{$\begin{array}{l}\text { Stages of Middle } \\
\text { and Late Pleistocene }\end{array}$} & $\begin{array}{l}\text { Fossil pollen assemblage } \\
\text { characters }\end{array}$ \\
\hline Early-glacial (e - ) & e El & e Sa & e We & & $\begin{array}{l}\text { High NAP. Few or no } \\
\text { thermophilous trees. }\end{array}$ \\
\hline Post-temperate (IV) & CrIV & Ho IV & Ee IV & & Pinus, Betula. \\
\hline Late-temperate (III) & $\mathrm{Cr}$ III & Ho III & Ee III & (Fl III) & $\begin{array}{l}\text { Carpinus, Abies, (Fagus), } \\
\text { Quercetum mixtum. }\end{array}$ \\
\hline Early-temperate (II) & Cr II & Ho II & Ee II & (F1 II) & Quercetum mixtum. \\
\hline Pre-temperate (I) & $\mathrm{CrI}$ & Ho I & Ee I & $(\mathrm{Fl} \mathrm{I})$ & Betula, Pinus. \\
\hline Late-glacial $(l-)$ & $l \mathrm{Be}$ & $l \mathrm{E} l$ & $l \mathrm{Sa}$ & $l \mathrm{We}$ & $\begin{array}{l}\text { High NAP, few or no } \\
\text { thermophilous trees. }\end{array}$ \\
\hline
\end{tabular}

Stage name symbols

Interglacials: Cr: Cromerian, Ho: Holsteinian, Ee: Eemian, (Fl: Flandrian, Post-glacial).

Glacials: Be: Beestonian, El: Elsterian, Sa: Saalian, We: Weichselian.

\section{Ref e rences}

Andersen, S. T.: Pollen analysis of the Quaternary marine deposits at Tornskov in South Jutland. Danmarks Geol. Unders. (iv), 4, 8, Kopenhagen, 1963. - - Interglacial succession and lake development in Denmark. The Palaeobotanist 15, 117, Lucknow 1966.

De Ridder, N. A. \& Zagwijn, W. J.: A mixed Rhine-Meuse deposit of Holsteinian age from the South-Eastern part of the Netherlands. Geologie en Mijnbouw 41, 125, s'Gravenhage 1962

Firbas, F.: Waldgeschichte Mitteleuropas, I, Jena 1949.

IVERSEN, J.: The bearing of glacial and interglacial epochs on the formation and extinction of plant taxa. Uppsala Univ. Arsskr. 6, 210, Uppsala 1958.

Jessen, K. \& Milthers, V.: Stratigraphical and palaeontological studies of interglacial freshwater deposits in Jutland and Northwest Germany. Danmarks Geol. Unders. (II), 48, Kopenhagen 1928.

Jessen, K., Andersen, S. T. \& Farrington, A.: The interglacial deposit near Gort, Co. Galway, Ireland. Proc. Roy. Irish Acad. 60 B, 1, Dublin 1959. 
von Post, L.: The prospect for pollen analysis in the study of the earth's climatic history. New Phytol. 45, 193, Cambridge 1946.

Selle, W.: Die Vegetationsentwicklung des Interglazials vom Typ Ober-Ohe. Abh. nat. Ver. Bremen 34, 33, Bremen 1955.

ŚRodoń, A.: Interglacial flora from Gościęcin near Kozle, Sudeten Foreland. Inst. Geol. Biul. 118, 7, Warsaw 1957.

Środoń, A. \& Golabowa, M.: Pleistocene flora of Bedlno. Inst. Geol. Biul. 100, 7, Warsaw 1956.

Szafer, W.: Pleistocene stratigraphy of Poland from the floristic point of view. Ann. Soc. Geol. Pologne 22, 1, Kraków 1953.

Turner, C.: The Middle Pleistocene deposits at Marks Tey, Essex. In preparation, 1968.

WATTS, W. A.: Interglacial deposits in Kildromin Townland near Herbertstown, Co. Limerick. Proc. Roy. Irish Acad. 65 B, 339, Dublin 1967.

West, R. G.: The Quaternary deposits at Hoxne, Suffolk. Phil. Trans. Roy. Soc. Lond., B, 239, London 1956.

Manuskr. eingeg. 16. 2. 1968.

Anschrift der Verf.: Dr. C. Turner und Dr. R. G. West, Cambridge, England, Botany School. 